\title{
Protolytic Properties of Dyes Embedded in Gelatin Films
}

\author{
Nataliya A. Nikitina, * Elena A. Reshetnyak, Nataliya V. Svetlova and \\ Nikolay O. Mchedlov-Petrossyan
}

\author{
Kharkov V. N. Karazin National University, Kharkov, 61077, Ukraine
}

\begin{abstract}
O filme de gelatina endurecida fixo em uma base transparente de triacetilcelulose pode ser utilizado como um suporte conveniente para indicadores ácido-base. Azul de bromofenol, verde de bromocresol, eosina, etil-eosina, $n$-decil-eosina, $n$-decil-fluoresceína, vermelho neutro e verde de malaquita foram incorporados nos filmes de gelatina por extração em meio aquoso sob condições apropriadas. A absorção de luz dos filmes dopados com corante exibe uma resposta ao $\mathrm{pH}$ de soluções tampão aquosas nas quais foram imersos. Valores reprodutíveis das constantes aparentes de dissociação dos indicadores, $\mathrm{pK}_{\mathrm{a}}^{\mathrm{app}}$, foram calculados pelo tratamento convencional dos valores de $\mathrm{pH}$ do tampão aquoso e também para a água absorvida nos filmes de gelatina. Os experimentos com $\mathrm{pH}$ abaixo e acima do ponto isoelétrico da gelatina (em torno de $\mathrm{pH}$ 5) resultaram em valores de $\mathrm{pK}_{\mathrm{a}}^{\mathrm{app}}$ semelhantes àqueles em meios micelares de tensoativos catiônicos e aniônicos, respectivamente. Os filmes de gelatina modificados por corantes podem ser recomendados para uso em sensores óticos e dispositivos similares.
\end{abstract}

The hardened gelatin film fixed on the transparent triacetylcellulose support can be utilized as a convenient carrier for acid-base indicator dyes. Bromophenol blue, bromocresol green, eosin, ethyleosin, $n$-decyleosin, $n$-decylfluorescein, neutral red, and malachite green were embedded into the gelatin films by extracting from aqueous media under appropriate conditions. The light absorption of dye-doped films exhibits a response to the $\mathrm{pH}$ values of aqueous buffer solutions, where they were soaked in. The well-reproducible indices of the apparent ionization constants, $\mathrm{pK}_{\mathrm{a}}^{\mathrm{app}}$, of the indicators were calculated by conventional equating the $\mathrm{pH}$ values of the bulk aqueous buffer and those of the 'internal' water into the gelatin films. The experiments with $\mathrm{pH}$ below and above the isoelectric point of gelatin (around $\mathrm{pH}$ 5) result in $\mathrm{pK}_{\mathrm{a}}^{\text {app }}$ values, which resemble those in micellar media of cationic and anionic surfactants, respectively. The dye-modified gelatin films can be recommended for use in optical sensors and related devices.

Keywords: dye-modified gelatin film, indicators, apparent ionization constants, medium effects

\section{Introduction}

This paper is devoted to the influence of hardened gelatin media on the spectral and acid-base properties of immobilized xanthene, sulfonephthalein, and some other dyes.

The immobilization of reagents in solid matrix (cellulose, ion-exchangers, polymers, silica, xerogels, etc. $)^{1-7}$ or using organized solutions, e.g., surfactant-based ones, ${ }^{8-12}$ modifies the properties of guest molecules owing to the change of the microenvironment.

Such modifications, or medium effects, are most studied and well documented for acid-base indicators. ${ }^{8,9}$ In this case, the influence of the microenvironment results in the shift

*e-mail: nikitina@univer.kharkov.ua of the indicator equilibrium as compared to that in aqueous media. The main reasons are the local polarity and the local electrical charge. The latter often (but not always) manifests itself in the decrease or increase in the 'apparent' $\mathrm{pK}_{\mathrm{a}}$ value, $\mathrm{pK}_{\mathrm{a}}^{\mathrm{app}}$, in the case of positive and negative local charges, respectively. ${ }^{8,9}$ In addition, the penetration of indicator dyes into micro-aggregates, both charged and uncharged, leads to the displacements of the absorption bands of the conjugate species of the acid-base pair.

Special type of immobilization of indicators is their sorption on polymers, such as polyacrylamide fiber (fluorescein, phenol red), ${ }^{1,2}$ polystyrene latex (rhodamine B, rhodamine 6G, malachite green), ${ }^{3}$ crosslinked co-polymer of styrene and divinylbenzene (phenol red, chlorophenol red, bromphenol blue, bromthymol blue, alizarin, 2,6-dichlorphenolindophenol), ${ }^{4,5}$ chitin gel 
(reactive violet 5, acid blue 74, direct red 28), ${ }^{6}$ in gelatin layer of photographic Agfa plates (Agfa Gevaert graphic gelatin film, 61101508; eosin, ethyleosin, methyleosin, uranin), ${ }^{7}$ protein molecules (coomassie brill blue, ${ }^{13}$ eosin $\mathrm{Y},{ }^{14}$ rose bengal ${ }^{15}$ ), methylcellulose and gelatinous films (acid blue 1, acid green 9, acid blue 15, acid violet 17), ${ }^{16}$ cotton fiber (acid violet 17, direct red 80). ${ }^{17}$ the behavior of some indicators ( $p$-nitrophenol, bromocresol purple, chlorophenol red, bromophenol blue, bromocresol green), solubilized in micelles of an ampholytic surfactant ${ }^{18}$ is also of interest.

The protolytic and spectral effects observed in the above systems were explained by preferable fixation of the neutral forms of indicators on the surface and in the body of the uncharged polymer, ${ }^{5,6,19}$ by electrostatic interaction of ionic indicator species with the net charge of the gel, ${ }^{6,7}$ by conformations of dye molecules, ${ }^{3}$ aggregation, ${ }^{16}$ and also in terms of hydrophobic interactions ${ }^{20}$ and hydrogen bond formation. ${ }^{6}$

Gelatin layers of photographic films were used as a medium for carrying out reactions of different types. ${ }^{16,21-26}$ Gelatin is actually a polydisperse mixture of low-molecular polypeptides, ${ }^{22}$ the molecules are pronouncedly anisotropic and asymmetric. In fact, the polymer contains a voluminous net of charges and some amount of free ions. Gelatin is a typical ampholyte; the averaged isoelectric point, $\mathrm{pH}_{\mathrm{ip}}$, of the so-called alkaline gelatin is within the $\mathrm{pH}$ range of 4.8 to $5.1 .{ }^{27}$

Owing to the long-chained molecules, cohered by a limited number of cross-linkages, the elasticity of gelatin films resembles that of rubber. Based on such polymeric arrays, it becomes possible to create matrix systems with rather uniform distribution of sterically available trapped molecules. This provides favorable conditions for promoting various chemical processes with participation of immobilized reactants. ${ }^{22}$

The aim of this study was to consider the behavior of dyes embedded in hardened gelatin films, wetted by water. For more objective examination, a set of indicator dyes with various charge types and different hydrophobicity was selected.

As probes for monitoring the local electrostatic potentials of the microenvironments, xanthenes and structurally similar compounds are often used. ${ }^{10,28-33}$ The dyes of such type are also utilized in sensor devices ${ }^{31,34,35}$ and for holographic record. ${ }^{32}$

We studied visible-spectroscopically the protolytic properties of four xanthene dyes: eosin, ethyl eosin, $n$-decyleosin, and $n$-decylfluorescein, two sulfonephthaleins: bromophenol blue and bromocresol green, a triphenylmethane dye malachite green, and an azine dye neutral red in the films, by measuring their transmittance after immersing them into aqueous buffer solutions of different $\mathrm{pH}$.

Attempts were made to sense the alterations of the electrostatic properties of gelatin in the above films along with variation of bulk water acidity. Also, the possibility of utilization of such dyed films in creating non-expandable test-materials for $\mathrm{pH}$ monitoring of aquatic media was estimated.

\section{Experimental}

\section{Chemicals}

Photographic films for offset printing manufactured by AGFA, with thickness of gelatin layer around $20 \mu \mathrm{m}$, fixed on the transparent triacetylcellulose support ${ }^{36}$ were used in this work. The samples used were colorless and transparent. Previously, the silver halides have been completely removed from the films using the solution of the developer $\mathrm{G} 101 \mathrm{c}$, containing hydroquinone CAS \# 123-31-9, and rapid fixer G 333c from Agfa Graphics NV (Belgium). Also, gelatin of technical quality was used for preparation of gelatin solutions. Bromophenol blue, bromocresol green, malachite green, and neutral red were from Shostka Chemical Plant, Ukraine, eosin and ethyleosin were from the collection of the Department of Physical Chemistry of Kharkov V. N. Karazin National University, the samples of $n$-decylfluorescein and $n$-decyleosin were kindly put at our disposal by Dr. V. I. Alekseeva, Research Institute of Organic Intermediates and Dyes, Moscow, Russia. Sodium $n$-dodecyl sulfate (SDS, 99\% purity) was used as commercially obtained. Photographic gelatin was used for preparing its aqueous solutions.

Stock solutions of indicators with concentrations $10^{-3}$ to $10^{-2} \mathrm{~mol} \mathrm{~L}^{-1}$ (except $n$-decyleosin, which initial concentration was one or two orders of magnitude lower) were prepared by dissolution of exactly weighed amounts of sulfonephthaleins, malachite green, and neutral red in water; in the case of xanthene dyes, ethanol with mass fraction $95.6 \%$ was used as solvent. All working solutions were prepared by dilution of stock solutions using distilled water.

Acetic acid, sodium acetate, $\mathrm{Na}_{2} \mathrm{HPO}_{4}, \mathrm{NaH}_{2} \mathrm{PO}_{4}$, glycine, $\mathrm{HCl}$, and $\mathrm{NaOH}$ were used to establish the required $\mathrm{pH}$ values. All acids and salts were of reagent grade. Sodium hydroxide stock solution was prepared using carbonate-free saturated alkali solution, was kept protected from the atmospheric $\mathrm{CO}_{2}$ and standardized by adipic acid. ${ }^{37}$ The values $\mathrm{pH}<3.5$ were produced by $\mathrm{HCl}$ solutions, $\mathrm{pH}$ around 5 by the acetate buffer, from 7 to 8 
by phosphate buffers, and from 8.5 to 10.5 by (glycine + $\mathrm{NaOH})$ mixtures. Alkaline media $(\mathrm{pH}>11)$ was made using $\mathrm{NaOH}$ stock solution diluted by $\mathrm{CO}_{2}$-free water.

\section{Apparatus}

Absorption spectra of dye solutions and dye-containing gelatin films were measured using KFK-3 (Russia) apparatus against reference solutions or film, containing all components except the indicator. The $\mathrm{pH}$ values of working solutions were determined using the glass electrode ESL-63-07 (Russia) in a cell with liquid junction (aqueous saturated $\mathrm{KCl}$ solution) with the $\mathrm{Ag} / \mathrm{AgCl}$ reference electrode EVL-1 M3 (Russia). The measurements were performed with the potentiometer P 307 (Russia) at $25.0{ }^{\circ} \mathrm{C} \pm 0.1$ according to the compensation scheme; the $\mathrm{pH}$ meter-millivoltmeter $\mathrm{pH}-121$ was used as a nil-instrument. The repeatability did not exceed $\pm 0.3 \mathrm{mV}$.

\section{Techniques}

\section{Modification of gelatin films}

A volume of $25 \mathrm{~mL}$ of indicator solution placed into the Petri dish and films with size $2.5 \times 3.5 \mathrm{~cm}$ were dipped in the solution at room temperature, without stirring; reagents concentration and $\mathrm{pH}$ values in solutions are shown in Table 1. The films were pulled out of solution with tweezers; washed with distilled water, acidified with $\mathrm{HCl}$ to the necessary $\mathrm{pH}$ value and dried at air for $1 \mathrm{~h}$. Thus prepared films were stored at room temperature in the dark; the dye concentrations in the films were 1-2 orders of magnitude higher as compared with those in the initial aquatic phases.

\section{The determination of the apparent ionization constants in} the two-phase system: water/gelatin film

Films with an immobilized indicator were dipped into the solution with a given $\mathrm{pH}$ value for $1 \mathrm{~min}$ and dried at air for $1 \mathrm{~h}$ at $18-22{ }^{\circ} \mathrm{C}$ before spectrophotometric measurements.
The acid-base equilibrium in the two-phase system can be described as follows:

$\overline{\mathrm{HB}} \rightleftharpoons \overline{\mathrm{B}}+\mathrm{H}^{+}, \mathrm{K}_{\mathrm{a}}^{\mathrm{app}}$

Here the $\overline{\mathrm{HB}}$ and $\overline{\mathrm{B}}$ denote the species located in the gelatin film (the charges are omitted for simplicity). The indices of the apparent constants were determined by the below formula: ${ }^{9-12}$

$\mathrm{pK}_{\mathrm{a}}^{\mathrm{app}}=\mathrm{pH}+\log \frac{\mathrm{A}_{\mathrm{B}}-\mathrm{A}}{\mathrm{A}-\mathrm{A}_{\mathrm{HB}}}$

The $\mathrm{pH}$ value refers to the bulk (aqueous) phase, $\mathrm{A}_{\mathrm{B}}$ and $\mathrm{A}_{\mathrm{HB}}$ are absorbances of the film at the given wavelength after complete conversion into the corresponding form, and $\mathrm{A}$ is absorbance at the current $\mathrm{pH}$. The ionic strength of the bulk phase (I) was as a rule 0.01 to $0.05 \mathrm{~mol} \mathrm{~L}^{-1}$.

For calculation of the $\mathrm{pK}_{\mathrm{a}}^{\mathrm{app}}$ values, the results of 3-5 independent series were used; the experiments were repeated beginning from the preparation of the films and immobilization of the dyes. Finally, 20-30 $\mathrm{pK}_{\mathrm{a}}^{\text {app }}$ values were utilized to obtain the averaged constant. The results obtained using different wavelengths $\left(\lambda_{\max } \pm 10 \mathrm{~nm}\right)$ coincide. The changes of the $\mathrm{pH}$ values of the bulk solutions, resulting from the dipping procedure, are negligible.

During the dipping process, the aqueous phase stayed colorless within the working range of $\mathrm{pH}$. The latter is limited by the conditions of dye extraction (Table 1). The color changes were reversible; for instance, the properties of bromophenol blue-containing films did not change after 30 to 50 soakings with solutions with different $\mathrm{pH}$ within the working acidity range. The air-dried films maintain their color during 1 year.

\section{Results and Discussion}

\section{The binding of dyes by the gelatin films}

The contact time of colorless films with indicator solutions, necessary for dye immobilization (Table 1),

Table 1. Conditions of dye immobilization into the gelatin films

\begin{tabular}{|c|c|c|c|}
\hline Indicator & Indicator concentration / $\left(\mathrm{mol} \mathrm{L}^{-1}\right)$ & $\mathrm{pH}$ & Immobilization time / $\mathrm{min}$ \\
\hline Sulfonephthaleins & $1 \times 10^{-4}$ & 1 & 30 \\
\hline Malachite Green & $2 \times 10^{-4}$ & $6-7$ & 30 \\
\hline Neutral Red & $3 \times 10^{-4}$ & $6-7$ & 30 \\
\hline$n$-Decylfluorescein ${ }^{\mathrm{a}}$, Eosin $^{\mathrm{a}}$ & $1 \times 10^{-4}$ & 3 & 60 \\
\hline Ethyleosin ${ }^{\mathrm{a}}$ & $1 \times 10^{-4}$ & 2 & 30 \\
\hline$n$-Decyleosin ${ }^{\mathrm{a}}$ & $1 \times 10^{-5}$ & 1 & 30 \\
\hline
\end{tabular}

aThe water solutions contained ethanol (mass fraction $8 \%$ ). 
was determined using the saturation curves. The latter were obtained by plotting the absorbance $v s$. dipping time. Under proper conditions, both acid and basic forms of indicator dyes studied can be extracted into the films. Owing to their hydrophobicity, the long-chained lipophilic dyes $n$-decylfluorescein and $n$-decyleosin always tend to be embedded into the films. The indicators neutral red and malachite green are preferably extracted within the $\mathrm{pH}$ range above the isoelectric point of gelatin $(\mathrm{pH}>5)$ in the form of cations $\mathrm{HR}^{+}$and $\mathrm{R}^{+}$, respectively (Figure 1), while anionic species $\mathrm{HR}^{-}$and $\mathrm{R}^{2-}$ of bromophenol blue, bromophenol green (Figure 2), and eosin as well as $\mathrm{R}^{-}$ions of ethyleosin (Figure 3 ) are readily bound at $\mathrm{pH}<5$.

Similar regularities were observed by binding of eosin $\mathrm{Y}$ with bovine serum albumin..$^{14}$ The dye does not bind with protein in alkaline medium $(\mathrm{pH} 9)$, because the macromolecule has mainly negative charge due to ionization<smiles></smiles>

Figure 1. The cations of neutral red $\left(\mathrm{HR}^{+}\right)$and malachite green $\left(\mathrm{R}^{+}\right)$. of amino acid residues, while the dye is in the form of dianion $\mathrm{R}^{2-}$. On the contrary, the positively charged surface of protein is able to bind the anionic form of the indicator rose bengal. ${ }^{15}$ Anions of $p$-nitrophenol, bromocresol purple, chlorophenol red, bromophenol blue, and bromocresol green can be bound both by neutral or positively charged surface of $n$-dodecyldimethylamineoxide micelles. ${ }^{18}$

Some specific peculiarities were observed with the dye neutral red. While the positively charged red form $\mathrm{HR}^{+}$was successfully inserted in the gelatin films in pure water, at $\mathrm{pH}$ 6-7, the dye immobilized in the yellow form $\mathrm{R}$ at $\mathrm{pH}>10$ became red $\left(\mathrm{HR}^{+}\right)$under immersion in acid solutions with $\mathrm{pH}<5$ and was not washed out, though the grid charge of gelatin gel is positive under such conditions. It might be supposed that in this case hydrophobic interactions and hydrogen bond formation overcome the electrostatic repulsion.<smiles>CN(C)c1ccc([C+](c2ccccc2)c2ccc(N(C)C)cc2)cc1</smiles><smiles>[X]C1=C(Br)C(=O)C(Br)=CC1=C(c1ccccc1S(=O)(=O)[O-])c1cc(Br)c(O)c(Br)c1[X]</smiles>

$\mathrm{HR}^{-}$

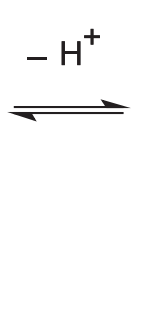<smiles>[X]C1=C(Br)C(=O)C(Br)=CC1=C(c1ccccc1S(C)(=O)=O)c1cc(Br)c(OC)c(Br)c1[X]</smiles>

$\mathrm{R}^{2-}$

Figure 2. The anions of bromophenol blue $(\mathrm{X}=\mathrm{H})$ and bromocresol green $\left(\mathrm{X}=\mathrm{CH}_{3}\right)$.

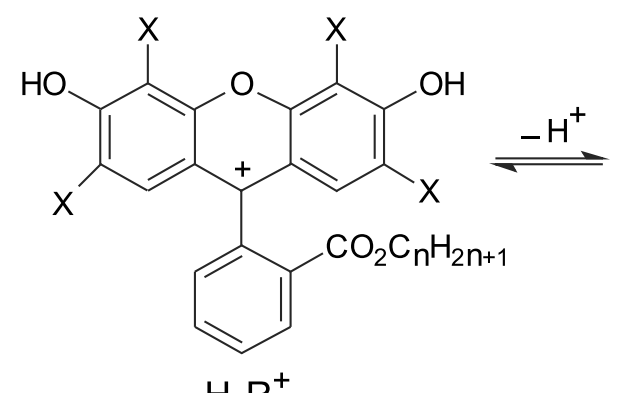<smiles>[X]c1cc2c(-c3ccccc3C(=O)O)c3cc([X])c(=O)c([X])c-3oc2c([X])c1O</smiles>

$\mathrm{HR}$<smiles>[X]c1cc2c(-c3ccccc3C(=O)O)c3cc([X])c(=O)c([X])c-3oc2c([X])c1OC</smiles>

$\mathrm{R}^{-}$

Figure 3. Ethyleosin $(\mathrm{X}=\mathrm{Br}, \mathrm{n}=2), n$-decyleosin $(\mathrm{X}=\mathrm{Br}, \mathrm{n}=10)$, and $n$-decylfluorescein $(\mathrm{X}=\mathrm{H}, \mathrm{n}=10)$. For ethyleosin and $n$-decyleosin, the cationic species $\mathrm{H}_{2} \mathrm{R}^{+}$appear only in strongly acidic media, ${ }^{11}$ not studied here. 
Interestingly, analogous effect was observed by studying the sorption and desorption of anionic dyes reactive purple 5 , acid blue 74 and direct red 28 on the chitin gel. ${ }^{38}$ Under the conditions favorable for sorption (pH 5.8) strong retention of indicators was provided by electrostatic interaction of sulfonate groups of the dyes with protonated amides of the gel $\left(\mathrm{pK}_{\mathrm{a} \text {,monomer }}=7.6\right)$. However, no desorption of indicator direct red was observed in alkaline medium at $\mathrm{pH} 10$, where the grid charge of the gel is negative. ${ }^{38}$

The positions of the absorption maxima of the airdried films in the visible region prove the non-aqueous microenvironment of the dye species, bound by the gelatin macromolecules.

Spectral characteristics of indicators immobilized in the gelatingel

The absorption bands of acid and basic forms of all the indicators under study, immobilized in gelatin film, are shifted as compared with those in aqueous solutions. The electronic absorption spectra of the conjugated forms of indicators in films and in solutions are exemplified in Figures 4 and 5.

Hypsochromic shifts of absorption maxima were observed for $\mathrm{HR}^{-}$species of bromophenol blue and bromocresol green, $\mathrm{HR}$ form of ethyleosin and $\mathrm{HR}^{+}$ion of neutral red, while the batochromic shifts were registered for basic forms of all indicators and acid form of malachite green $\left(\mathrm{R}^{+}\right)$and molecular species of $n$-decylfluorescein (HR) (Table 2).

For the above anionic dyes analogous effects were observed in micellar solutions of cationic surfactants, e.g., $N$-cetylpyridinium chloride and in microemulsions

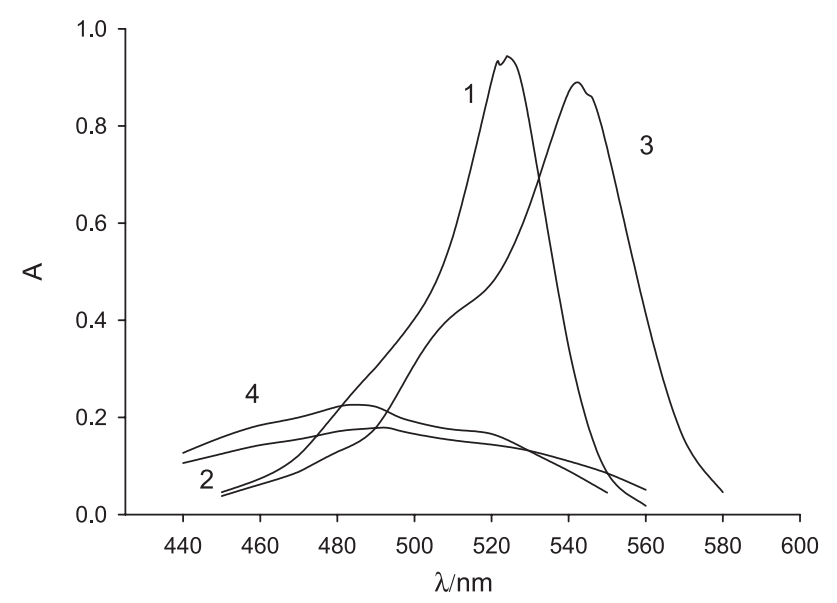

Figure 4. Absorption spectra of the form $\mathrm{R}^{-}, \mathrm{pH}=3.0-5.0(1,3)$, and $\mathrm{HR}, \mathrm{pH}=0.50-0.55(2,4)$ of ethyleosin in aqueous solution with ethanol mass fraction $8 \%$, dye concentration $1.00 \times 10^{-5} \mathrm{~mol} \mathrm{~L}^{-1}(1,2)$ and in the gelatin film $(3,4)$. based on these surfactants. ${ }^{9,11,39,40}$ In turn, for neutral red and malachite green similar spectral shifts were registered in micellar solutions and microemulsions of an anionic surfactant SDS, in aqueous solutions of anionic calixarens, in suspensions of liposomes. ${ }^{9-12}$ Batochromic shift of $10 \mathrm{~nm}$ was observed for basic forms of eosin, ethyleosin, methyleosin, and uranin (disodium salt of fluorescein), captured in gelatin layer of photographic plates manufactured by Agfa (Agfa Gevaert graphic gelatin film, 61101508). ${ }^{7}$ The alterations of $\lambda_{\text {max }}$ give evidence for interaction of dyes with the gelatin gel..$^{14,15}$ The closeness of the $\lambda_{\max }$ values in gelatin films and in micellar solutions of ionic surfactants allows to expect that the microenvironment of dyes in two media is similar. ${ }^{33,35}$ The maxima of the spectra of neutral molecular forms of ethyleosin and $n$-decyleosin are expressed less distinctly (Figure 4$)$. The neutral form of eosin $\left(\mathrm{H}_{2} \mathrm{R}\right)$, captured in the films, is not colored. This indicates the shift of tautomeric equilibrium of this neutral form from the quinonoid, which is colored like that of ethyleosin (Figure 4, curves 2, 4) toward the colorless lactone (Figure 6). ${ }^{39,40}$

It is worth to point out that disappearance of fluorescence was observed for xanthenes during injection of it in gelatin film. It can be caused both by concentration quenching and dimerization of the dyes in the gelatin matrix. ${ }^{33}$ However, we have not registered alterations of the absorption spectra typical for dimer formation.

Apparent ionization constants of indicators in two-phase system: water/gelatin film

In order to determine the $\mathrm{pK}_{\mathrm{a}}^{\text {app }}$ values, the absorbance of the dye-doped films was plotted against the $\mathrm{pH}$ values of aqueous solutions, where films were dipped into. The

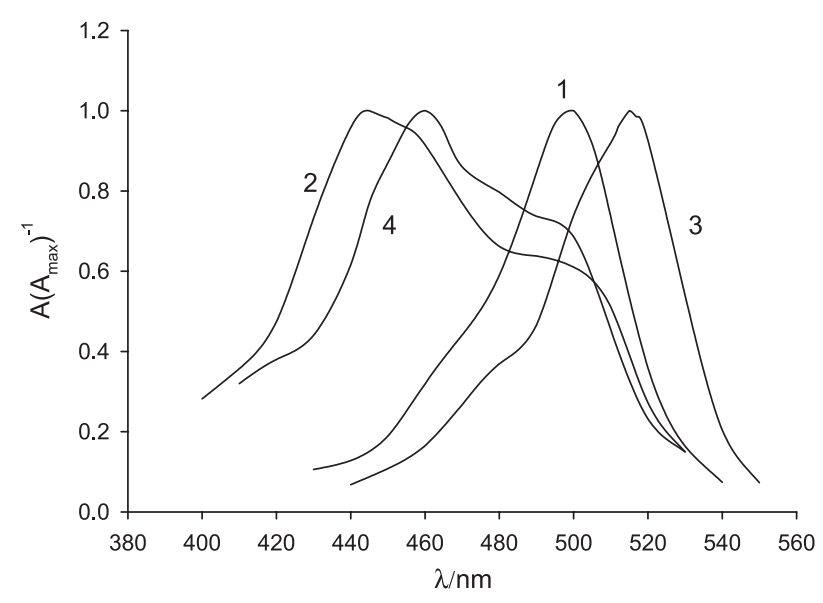

Figure 5. Normalized absorption spectra of $n$-decyfluorescein in aqueous solution with ethanol mass fraction $8 \%$, dye concentration $1.00 \times 10^{-5} \mathrm{~mol} \mathrm{~L}^{-1}(1,2)$ and in the gelatin film $(3,4) ; \mathrm{pH}=12.0$ (1), $4.0(2), 11.0(3)$ and 1.5 (4). 
Table 2. The $\lambda_{\max } / \mathrm{nm}$ and $\mathrm{pK}_{\mathrm{a}}^{\mathrm{app}}$ values of indicators and medium effects $\left(\Delta \mathrm{pK}_{\mathrm{a}}=\mathrm{pK}_{\mathrm{a}}^{\mathrm{app}}-\mathrm{pK}_{\mathrm{a}}^{\mathrm{w}}\right)$.

\begin{tabular}{|c|c|c|c|c|c|c|}
\hline \multirow{3}{*}{ Indicator } & \multicolumn{2}{|c|}{$\lambda \max \left(\lambda_{\max }^{\text {water }}\right)$} & \multirow{3}{*}{$\mathrm{pK}_{\mathrm{a}}^{\mathrm{app}}$ (gelatin) } & \multicolumn{3}{|c|}{$\Delta \mathrm{pK}_{\mathrm{a}}$} \\
\hline & \multirow{2}{*}{ acidic } & \multirow{2}{*}{ basic } & & \multirow[t]{2}{*}{ Gelatin } & \multicolumn{2}{|c|}{ Surfactant micelles s $^{9,29,38}$} \\
\hline & & & & & anionic $^{\mathrm{a}}$ & cationic $^{\mathrm{b}}$ \\
\hline Ethyleosin & $482\left(-^{c}\right)$ & $543\left(520^{d}\right)$ & $1.66 \pm 0.09$ & -0.24 & - & -1.9 \\
\hline Bromophenol Blue & $416(440)$ & $604(590)$ & $2.22 \pm 0.17$ & -1.98 & - & -2.16 \\
\hline$n$-Decyleosin & - & $545\left(520^{d}\right)$ & $2.23 \pm 0.08$ & $0.3^{\mathrm{e}}$ & $2.6^{\mathrm{e}}$ & - \\
\hline $\operatorname{Eosin}(\mathrm{I})$ & $-{ }^{\mathrm{f}}$ & $-g$ & $2.54 \pm 0.17$ & -0.27 & - & -2.3 \\
\hline Bromocresol Green & $433(443)$ & $634(616)$ & $3.54 \pm 0.12$ & -1.36 & - & -1.68 \\
\hline Eosin (II) & $-\mathrm{g}$ & $534\left(518^{\mathrm{d}}\right)$ & $4.48 \pm 0.16$ & 0.71 & - & -0.91 \\
\hline Neutral Red & $505(534)$ & $462(450)$ & $8.83 \pm 0.08$ & 2.30 & $2.3^{\mathrm{h}}$ & - \\
\hline Malachite Green & $638(613)$ & colorless & $12.44 \pm 0.10$ & 5.4 & 4.6 & - \\
\hline$n$-Decylfluorescein & $460\left(445^{\mathrm{d}}\right)$ & $515\left(495^{\mathrm{d}}\right)$ & see the text & - & $2.65^{\mathrm{i}}$ & -1.37 \\
\hline
\end{tabular}

${ }^{a}$ In SDS micellar solutions, $\mathrm{I}=0.05 \mathrm{~mol} \mathrm{~L}^{-1}(\mathrm{NaCl}) .{ }^{b} \mathrm{In} N$-cetylpyridinium chloride micellar solutions, $\mathrm{I}=0.05 \mathrm{~mol} \mathrm{~L}^{-1}(\mathrm{KCl}) .^{39} \mathrm{c}^{\mathrm{c}} \mathrm{he}$ neutral species $\mathrm{HR}$ of ethyleosin is poorly soluble in water; at $8 \%$ mass ethanol, at $\mathrm{pH}$ around 0.5 , the spectrum with $\lambda_{\max }=492 \mathrm{~nm}$ may reflect the appearance of the traces of $\mathrm{R}^{-}$anions. ${ }^{\mathrm{d}} 8 \%$ mass ethanol. ${ }^{\mathrm{e}}$ The $\mathrm{pK}_{\mathrm{a}}^{\mathrm{w}}$ is equated to that of ethyleosin, $\mathrm{pK}_{\mathrm{a}}^{\mathrm{w}}=1.9{ }^{\mathrm{f}}{ }^{\mathrm{f}}$ In gelatin films the $\mathrm{H}_{2} \mathrm{R}$ species is practically colorless, in aquatic media $\lambda_{\max }=480-485 \mathrm{~nm} .{ }^{38} \mathrm{~g}$ The complete $\mathrm{HR}^{-}$spectrum was not singled out. ${ }^{\mathrm{h}}$ In the literature ${ }^{10}$ the $\Delta \mathrm{pK}_{\mathrm{a}}$ varies from 2.7 to 2.4 in 2 to 10 mass fraction $\%$ of SDS solutions, without supporting electrolyte. ${ }^{\text {TTe }} \mathrm{pK}_{\mathrm{a}}^{\mathrm{w}}$ is equated to that of ethylfluorescein, $\mathrm{pK}_{\mathrm{a}}^{\mathrm{w}}=6.31 .{ }^{9}$

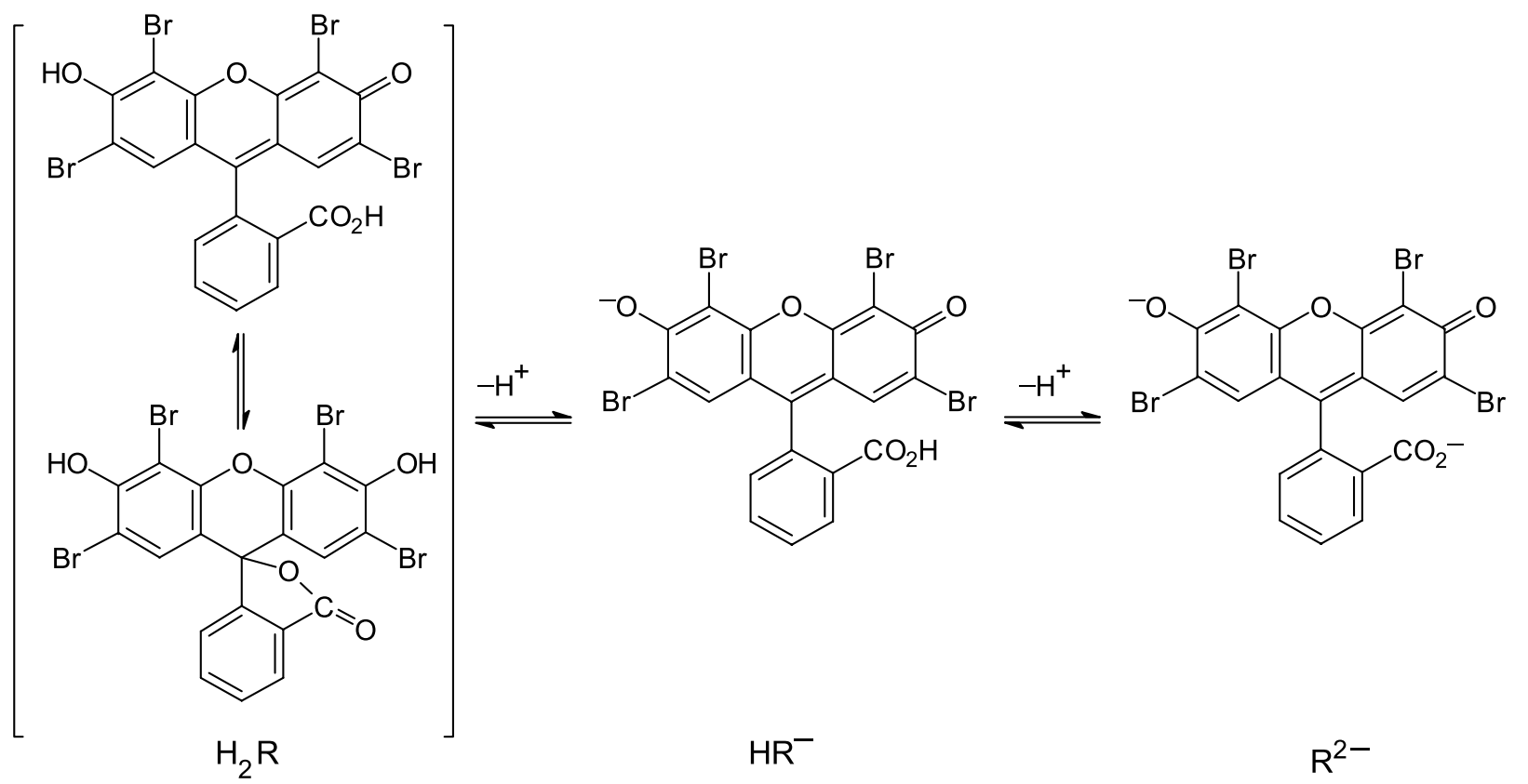

Figure 6. Protolytic equilibrium of eosin.

dependences of the fraction of deprotonated form $v s . \mathrm{pH}$ are represented in Figure 7.

According to recent data, the content of water in hardened gelatin, also manufactured using the photographic films, is around 40 moles per $\mathrm{kg}$; after heating up to $90{ }^{\circ} \mathrm{C}$ for $1 \mathrm{~h}$ near $80 \% \mathrm{H}_{2} \mathrm{O}$ was removed..$^{41} \mathrm{It}$ is reasonable to consider this fraction of water as forming an internal aqueous medium within the gelatin film, while the rest $\mathrm{H}_{2} \mathrm{O}$ molecules are strongly bound by the macromolecules. Our experimental data, given below, are treated assuming that the $\mathrm{pH}$ value of the internal water, being constant within the whole massive of the film, is determined by the acidity of the solution, where the film is dipped in. Thus, the internal $\mathrm{pH}$ is conventionally equated to the bulk (external) buffer $\mathrm{pH}$ value, equation 2 . The difference in the $\mathrm{pH}$ value of aqueous buffer solution and that in the microenvironment of the indicator dye is contributed into the $\mathrm{pK}_{\mathrm{a}}^{\text {app }}$ value, causing its deviation from the true $\mathrm{pK}_{\mathrm{a}}$ value into the macromolecular phase. Naturally, the $\mathrm{pH}$ variation results in the alteration of the 


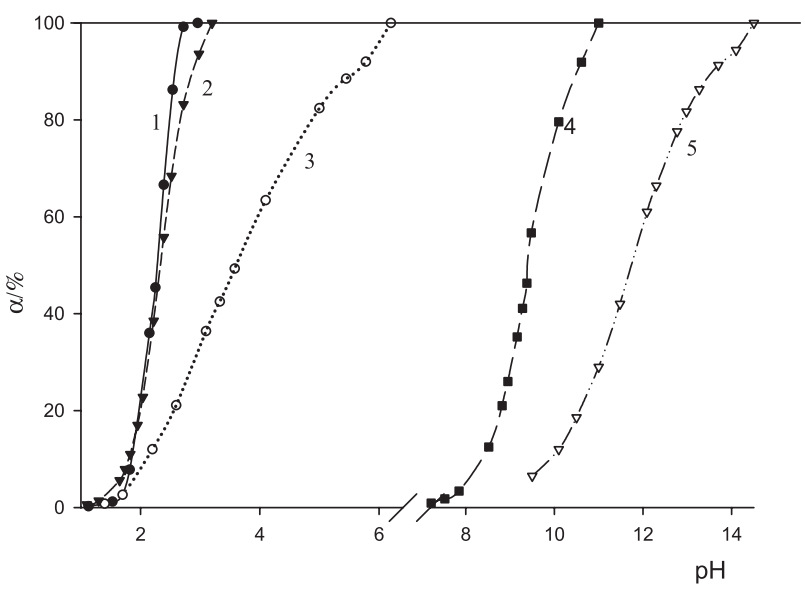

Figure 7. Dependence of deprotonation degree of dyes, immobilized in the gelatin film, on $\mathrm{pH}$ of external buffer solutions; 1 - bromophenol blue, 2 - ethyleosin $\left(I=0.05 \mathrm{~mol} \mathrm{~L}^{-1}\right.$ at $\left.\mathrm{pH} \geq 1.3\right), 3$ - bromocresol green, 4 - neutral red, 5 - malachite green.

gird charge of the macromolecules owing to acid-base interactions of amino acid residues; the counterions are located in the internal water.

The numerical data are compiled in Table 2. In such systems (see Introduction), the following expression should be used for the $\mathrm{pK}_{\mathrm{a}}^{\text {app }}$ value: ${ }^{9}$

$\mathrm{pK}_{\mathrm{a}}^{\mathrm{app}}=\mathrm{pK}_{\mathrm{a}}^{\mathrm{w}}+\log \frac{\gamma_{\mathrm{B}}}{\gamma_{\mathrm{HB}}}-\frac{\Psi \mathrm{F}}{2.3 R \mathrm{~T}}=\mathrm{pK}_{\mathrm{a}}^{\mathrm{i}}-\frac{\Psi \mathrm{F}}{2.3 R \mathrm{~T}}$

Here $\mathrm{pK}_{\mathrm{a}}^{\mathrm{w}}$ is the thermodynamic $\mathrm{pK}_{\mathrm{a}}$ in water, $\Psi$ is the local electrostatic potential, $\gamma_{\mathrm{B}}$ and $\gamma_{\mathrm{HB}}$ are activity coefficients of transfer of corresponding species from water to the gelatin phase, $R$ is the gas constant and $\mathrm{T}$ is absolute temperature. The index of the so-called intrinsic constant, $\mathrm{pK}_{\mathrm{a}}^{\mathrm{i}}$, equals to the sum $\mathrm{pK}_{\mathrm{a}}^{\mathrm{w}}+\log \left(\gamma_{\mathrm{B}} / \gamma_{\mathrm{HB}}\right)$. Equation 3 allows to explain the medium effects, $\Delta \mathrm{pK}_{\mathrm{a}}$, i.e., the deviations of $\mathrm{pK}_{\mathrm{a}}^{\mathrm{app}}$ from $\mathrm{pK}_{\mathrm{a}}^{\mathrm{w}}$. Indeed, if the $\gamma_{\mathrm{B}} / \gamma_{\mathrm{HB}}$ quantity is close to unity and, hence, $\mathrm{pK}_{\mathrm{a}}^{\mathrm{i}} \rightarrow \mathrm{pK}_{\mathrm{a}}^{\mathrm{w}}$, then the $\Psi$ value governs the medium effect. However, in the interfacial layers of surfactant micelles, phospholipid liposomes, microemulsion, etc., the $\mathrm{pK}_{\mathrm{a}}^{\mathrm{i}}$ value as a rule differs from $\mathrm{pK}_{\mathrm{a}}^{\mathrm{w}}$, thus indicating the 'non-aqueous' character of the microenvironments. ${ }^{9}$

The net charge of gelatin films, and hence, the electrostatic potential value, is changing along with variation of $\mathrm{pH}$ due to the ampholytic nature of gelatin. Therefore, according to equation 3 , the $\mathrm{pK}_{\mathrm{a}}^{\text {app }}$ should vary depending on the working $\mathrm{pH}$ region.

The $\mathrm{pK}_{\mathrm{a}}^{\mathrm{app}}$ and $\Delta \mathrm{pK}_{\mathrm{a}}$ of the dyes determined at $\mathrm{pH}$ values below the isoelectric point $\left(\mathrm{pH}_{\mathrm{ip}} c a\right.$. 5) resemble to more or less extent those determined in micellar solutions of cationic surfactants, ${ }^{9,40}$ cationic surfactant-based microemulsions, ${ }^{11}$ and cationic calixarenes. ${ }^{43}$
For the dye neutral red, the color transition occurs at $\mathrm{pH}$ values well above the $\mathrm{pH}_{\mathrm{ip}}$. Hence, the $\mathrm{pK}_{\mathrm{a}}^{\text {app }}$ value (Table 2) is close to that determined in aqueous SDS micellar solutions. ${ }^{10}$ The binding of this indicator to an anionic polyelectrolyte also results in a substantial increase in $\mathrm{pK}_{\mathrm{a}}^{\mathrm{app}}$ : in poly(sodium styrene sulphonate) aqueous solutions, the $\Delta \mathrm{pK}_{\mathrm{a}}=1.7$ value was registered. ${ }^{43}$

The results obtained with malachite green are of especial interest. At high and medium $\mathrm{pH}$ in aqueous media, this cationic indicator slowly converts into the colorless carbinol $\left(\mathrm{R}^{+} \rightleftharpoons \mathrm{ROH}+\mathrm{H}^{+}\right) .^{43,44}$ The equilibrium $\mathrm{pK}_{\mathrm{a}}^{\mathrm{w}}$ value equals to $6.92-7.10,{ }^{44-48}$ while the non-equilibrium color transition corresponds to $\mathrm{pH} 11.5-14.0 .^{49}$ Indeed, we determined the 'observed' value $\mathrm{pK}_{\mathrm{a}}^{\mathrm{w}}=11.94 \pm 0.11$ in aqueous diluted $\mathrm{NaOH}$ solutions by registering the absorbance within $1 \mathrm{~min}$ after mixing. ${ }^{50}$ Contrary to aqueous systems, in the gelatin films no color change in time was observed. The $\mathrm{pK}_{\mathrm{a}}^{\mathrm{app}}=12.44$ should be considered as a true value, and the $\Delta \mathrm{pK}_{\mathrm{a}}=5.4$ value for malachite green, together with the $\Delta \mathrm{pK}_{\mathrm{a}}=2.3$ value for neutral red, proves the negative net charge of the gelatin structures bearing the indicator dyes.

In aqueous SDS micellar solutions, in accordance with the report of Dutta and associates, ${ }^{51}$ practically no changes in malachite green absorbance in time were registered. The $\mathrm{pK}_{\mathrm{a}}^{\text {app }}$ value $11.62 \pm 0.09$ was determined at dye concentration $1.00 \times 10^{-5} \mathrm{~mol} \mathrm{~L}^{-1}$ in $0.01 \mathrm{~mol} \mathrm{~L}^{-1} \mathrm{SDS}$ solutions; $\mathrm{I}=0.05 \mathrm{~mol} \mathrm{~L}^{-1}$ (phosphate buffer solution + $\mathrm{NaCl}$ ), $2 \mathrm{~h}$ after preparation of working solutions. In $(0.75-6) \times 10^{-5} \mathrm{~mol} \mathrm{~L}^{-1}$ aqueous solutions of poly(sodium styrene sulphonate), Basahl et al. ${ }^{52}$ reported somewhat lower $\mathrm{pK}_{\mathrm{a}}$ values, 10.40-11.15, as determined at dye concentration $1.5 \times 10^{-5} \mathrm{~mol} \mathrm{~L}^{-1}$.

The case of eosin is more complicated due to dibasic character of this acid, with two overlapping ionization steps. Indeed, in the pH-dependences of absorbance at proper wavelengths, this is clearly seen due to existence of two inflection points (see Supplementary Information). For calculation of the $\mathrm{pK}_{\mathrm{a} 1}$ and $\mathrm{pK}_{\mathrm{a} 2}$ values, the program CLINP $^{53}$ was used. The data of three separate experimental series were processed, using independently prepared gelatin films with the immobilized dye.

The increase in the $\mathrm{pK}_{\mathrm{a} 2}$ value of eosin, as compared with the value in aqueous solutions, gives evidence for the decrease in the positive net charge of gelatin along with approaching to the $\mathrm{pH}_{\mathrm{ip}}$ value. Here, the contribution of the last item in equation 3 is small, and $\mathrm{pK}_{\mathrm{a}}^{\mathrm{app}} \rightarrow \mathrm{pK}_{\mathrm{a}}^{\mathrm{i}}$. In turn, the latter is always higher than $\mathrm{pK}_{\mathrm{a}}^{\mathrm{w}}$ for the second ionization step of eosin on going from water to micelles of non-ionic surfactants ${ }^{54}$ and solutions of non-ionic polymers. ${ }^{55}$

In another paper, ${ }^{56}$ the character of the dependence of absorbance at $552 \mathrm{~nm}$ (eosin concentration of 
$\left.1.5 \times 10^{-4} \mathrm{~mol} \mathrm{~L}^{-1}\right)$ on $\mathrm{pH}$ in water with gelatine mass fraction $0.05 \%$ addition indicates that $\mathrm{pK}_{\mathrm{a} 2}>4$.

The $\mathrm{pH}$-induced color changes of the films can be easily observed by the naked eye (Table 3 ).

Table 3. The color transitions of gelatin films with various embedded dyes

\begin{tabular}{lcc}
\hline $\begin{array}{l}\text { Immobilized } \\
\text { indicator }\end{array}$ & $\begin{array}{c}\text { The pH values of the } \\
\text { bulk aqueous phase }\end{array}$ & $\begin{array}{c}\text { The color of the } \\
\text { gelatin film }\end{array}$ \\
\hline Bromophenol Blue & $<1.5$ & yellow \\
& 2.5 & green \\
& $3.0-5.0$ & blue \\
Bromocresol Green & $<2.5$ & yellow \\
& 3.5 & green \\
Neutral Red & $4.5-5.0$ & blue \\
& $<8.0$ & red \\
Malachite Green & 9.0 & orange \\
& $>10$ & yellow \\
Eosin & $5.0-11.0$ & bluish-green \\
& 12.0 & light-blue \\
& $>13$ & colorless \\
Ethyleosin & $<1.5$ & colorless \\
& 2.0 & light-pink \\
$n$-Decyleosin & $3.0-5.0$ & rose \\
$n$-Decylfluorescein & $<0.5$ & yellow-orange \\
& 1.0 & orange \\
& $2.0-5.0$ & rose \\
& $<0.5$ & yellow-orange \\
& 1.0 & orange \\
& $2.0-5.0$ & rose \\
& $<2.0$ & yellow \\
& $>10.0$ & from
\end{tabular}

Note, that these dyes, except the most hydrophobic ones (neutral red, $n$-decyleosin, and $n$-decylfluorescein), release from the films dipped into aquatic systems with "unfavorable" pH (see above). Hence, their species are unable to hold in the internal water if not fixed at the gelatin macromolecules.

For more precise monitoring of the acidity of solutions, for example, in sensor devices, the spectroscopic measurements can be used. The change of the gird charge of gelatin along with $\mathrm{pH}$ variation manifests itself most distinctly in the case of $n$-decylfluorescein (Figure 8).

The corresponding color transition varies from $\mathrm{pH} 2$ to 10. Actually, this is in accordance with the $\mathrm{pK}_{\mathrm{a}}^{\text {app }}$ values (4.9-5.5) and (7.9-9.0) in cationic and anionic surfactant micelles respectively, depending on the bulk ionic strength. ${ }^{9}$ Also, the interfering of the first step, i.e., the dissociation of the cation $\mathrm{H}_{2} \mathrm{R}^{+}$, cannot be excluded; the corresponding $\mathrm{pK}_{\mathrm{a}}^{\mathrm{app}}$ values in two types of ionic micelles are (0.8-1.3) and (4.0-5.2) respectively. ${ }^{9}$ Interestingly, such behavior of $n$-decylfluorescein was also observed in the LangmuirBlodgett carboxylic acid-based films. ${ }^{33,35}$ In contrast, for a similar dye, 2,7- $n$-dihexyl- $n$-octadecylfluorescein embedded

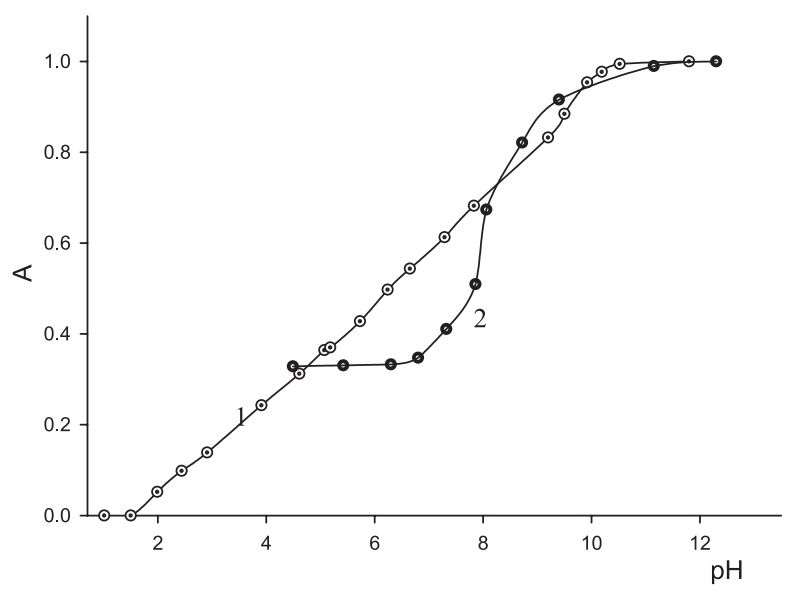

Figure 8. Dependence of $n$-decylfluorescein absorbance at $515 \mathrm{~nm}$ in gelatin films on $\mathrm{pH}$ of buffer solutions where they were soaked in (1) and at $500 \mathrm{~nm}$ in gelatin solutions with mass fraction $1 \%$ on $\mathrm{pH}$ of the bulk phase (2). $\mathrm{I}=0.05 \mathrm{~mol} \mathrm{~L}^{-1}$ at $\mathrm{pH} \geq 1.3$.

into a polyurethane-based film, the transition from HR to $\mathrm{R}^{-}$occurs within a normal $\mathrm{pH}$ range; $\mathrm{pK}_{\mathrm{a}}^{\mathrm{app}}=8.5 .^{57}$

These results are in agreement with some other works, where the change of the interfacial charge and $\Psi$ values, caused by acid-base interactions of interfacial functional groups, manifests itself in the alteration of the $\mathrm{pK}_{\mathrm{a}}^{\text {app }}$ values of the bound indicator dyes. ${ }^{12,18,28}$

With some other indicators, the $\mathrm{pK}_{\mathrm{a}}^{\mathrm{app}}$ drift was also registered, however, within a narrow $\mathrm{pH}$ region and not so distinct. Probably, the long hydrophobic hydrocarbon chain, fixing the dye in a definite constant position in the gelatin microenvironment, causes the peculiar behavior of $n$-decylfluorescein (in the case of $n$-decyleosin, such expressed $\mathrm{pK}_{\mathrm{a}}^{\mathrm{app}}$ alteration was not observed, because the complete ionization of this indicator occurs already in the acidic $\mathrm{pH}$ region, much lower than $\mathrm{pH}_{\mathrm{ip}}$ ).

The increase in the ionic strength of the aqueous buffer solutions, where the films were dipped in, from 0.05 to $0.50 \mathrm{~mol} \mathrm{~L}^{-1}(\mathrm{NaCl})$ displayed no distinct influence on the $\mathrm{pK}_{\mathrm{a}}^{\mathrm{app}}$ values of $n$-decylfluorescein.

The $p K_{a}^{\text {app }}$ values of indicators in aqueous solutions of gelatin

Unusual behavior of $n$-decylfluorescein in the gelatin film impelled us to examine the acid-base equilibrium of the dye in gelatin solutions. Solutions with gelatin mass fraction $1 \%$ were used; further increase in the concentration resulted in high turbidity, which hinders the spectrophotometric measurements. The "titration curve" of $n$-decylfluorescein in gelatin solutions is of common type and thus differs essentially from that in gelatin films (Figure 8 ). The $\mathrm{pK}_{\mathrm{a}}^{\mathrm{app}}=8.17$ value (Table 4 ) is close to that in micelles of anionic surfactants. This value is markedly 
Table 4. The $\lambda_{\max } / \mathrm{nm}$ and $\mathrm{pK}_{\mathrm{a}}^{\text {app }}$ values of indicators in water and in gelatin solution $(\omega=1 \%), \mathrm{I}=0.05 \mathrm{~mol} \mathrm{~L}^{-1}(\mathrm{NaCl}+$ buffer components)

\begin{tabular}{|c|c|c|c|c|c|}
\hline \multirow[t]{2}{*}{ Indicator } & \multicolumn{2}{|c|}{$\lambda_{\max }\left(\lambda_{\max }^{\text {water }}\right)$} & \multirow{2}{*}{$\begin{array}{c}\mathrm{pK}_{\mathrm{a}}^{\mathrm{app}} \\
\text { (gelatin solution) }\end{array}$} & \multirow[t]{2}{*}{$\mathrm{pK}_{\mathrm{a}}^{\mathrm{w}} 9,10$} & \multirow{2}{*}{$\begin{array}{c}\mathrm{pK}_{\mathrm{a}}^{\mathrm{app}} \\
{\text { (in micellar solution) })^{9,29,39}}\end{array}$} \\
\hline & acidic & basic & & & \\
\hline Bromocresol Green & $450(443)$ & $619(616)$ & $4.80 \pm 0.12$ & 4.90 & $3.22^{\mathrm{a}}$ \\
\hline Neutral Red & $537(534)$ & $457(450)$ & $6.75 \pm 0.02$ & 6.5 & $8.8^{\mathrm{b}, \mathrm{c}}$ \\
\hline$n$-Decyleosin & $490\left(-{ }^{d}\right)$ & $542\left(520^{\mathrm{e}}\right)$ & $1.73 \pm 0.02$ & - & $1.18^{\mathrm{f}, \mathrm{g}}$ \\
\hline$n$-Decylfluorescein & $445\left(445^{\mathrm{e}}\right)$ & $500\left(495^{\mathrm{e}}\right)$ & $8.17 \pm 0.19$ & - & $8.96 \pm 0.04^{\mathrm{b}, \mathrm{h}}$ \\
\hline
\end{tabular}

${ }^{a}$ In micellar solutions of $N$-cetylpyridinium chloride, $\mathrm{I}=0.05 \mathrm{~mol} \mathrm{~L}^{-1}(\mathrm{KCl})$. ${ }^{\text {in }} \mathrm{SDS}$ micellar solutions, $\mathrm{I}=0.05 \mathrm{~mol} \mathrm{~L}^{-1}(\mathrm{NaCl}) .{ }^{\mathrm{c}} \mathrm{In}$ the literature ${ }^{10}$ the $\Delta \mathrm{pK}_{\mathrm{a}}$ varies from 2.7 to 2.4 in 2 to 10 mass \% SDS solutions, without supporting electrolyte. ${ }^{\mathrm{d}}$ See Table $2 .{ }^{\mathrm{e}} 8$ mass $\%$ ethanol. ${ }^{\mathrm{f}}$ In micellar solutions of cetyltrimethylammonium chloride, $\mathrm{I}=4.0 \mathrm{~mol} \mathrm{~L}^{-1}(\mathrm{KCl})$. ${ }^{\mathrm{g}}$ For ethyleosin in $N$-cetylpyridinium chloride micellar solutions, $\mathrm{I}=0.05 \mathrm{~mol} \mathrm{~L}{ }^{-1}(\mathrm{KCl})$, $\mathrm{pK}_{\mathrm{a}}^{\mathrm{app}}=0.5 \cdot{ }^{39 \mathrm{~h}}=0.05 \mathrm{~mol} \mathrm{~L}^{-1}(\mathrm{NaCl}) \cdot{ }^{9}$

higher than that in water $\left(\mathrm{pK}_{\mathrm{a}}^{\mathrm{w}}=6.3\right)$, as equated to the $\mathrm{pK}_{\mathrm{a}}^{\mathrm{w}}$ value of the water-soluble analogue, ethylfluorescein. ${ }^{9}$

The binding of the species of $n$-decylfluorescein, as well as of $n$-decyleosin, by the gelatin macromolecules is ensured by their insolubility in pure water. However, contrary to the spectra in gelatin films, the absorption band positions in gelatin solutions are closer to those of their analogues (ethylfluorescein and ethyleosin) in water. Hence, the microenvironments in gelatin solutions are probably more hydrated than in the gelatin films. The $\lambda_{\max }=500 \mathrm{~nm}$ value of $n$-decylfluorescein anion, $\mathrm{R}^{-}$, coincides with that in SDS micelles, while in the case of $n$-decyleosin the band position $(542 \mathrm{~nm})$ is closer to those in nonionic and cationic micelles (540-544 nm), than in anionic ones $(535 \mathrm{~nm}){ }^{29}$ The $\mathrm{pK}_{\mathrm{a}}^{\text {app }}$ value of $n$-decyleosin, determined within the $\mathrm{pH}$ 0.5-3.0 (Table 3), is with 1.73 lower than the value 2.61 in micellar solutions of nonionic Tween-80, and even more so than $\mathrm{pK}_{\mathrm{a}}^{\mathrm{app}}=4.53$ in SDS micellar media at an ionic strength of $0.05 \mathrm{~mol} \mathrm{~L}^{-1}(\mathrm{NaCl}) .{ }^{29}$

In fact, the behavior of the lipophilic dyes in gelatin solutions is in agreement with the re-charging of the gelatin macromolecule on going from $\mathrm{pH}<5$ to $\mathrm{pH}>5$ in the aquatic medium.

We also determined the $\mathrm{pK}_{\mathrm{a}}^{\mathrm{app}}$ values of bromocresol green and neutral red in gelatin solution (Table 4). Contrary to the lipophilic xanthenes, the binding of the dyes species seems to be not complete, judging from the positions of their absorption maxima, and hence the discussion of the $\mathrm{pK}_{\mathrm{a}}^{\mathrm{app}}$ values is not appropriate here.

\section{Conclusions}

Cationic indicators neutral red and malachite green are readily extracted into the gelatin films at $\mathrm{pH}$ over the $\mathrm{pH}_{\mathrm{ip}}$ value of gelatin, while anionic ones, bromophenol blue, bromophenol green, eosin, and ethyleosin correspondingly at $\mathrm{pH}<5$. This is in agreement with the net charge of the macromolecules. The long-chained lipophilic dyes $n$-decylfluorescein and $n$-decyleosin always tend to be embedded into the films.
The shifts of the absorption bands of the indicators and the change of their $\mathrm{pK}_{\mathrm{a}}^{\mathrm{app}}$ values as compared with the corresponding data in aqueous media prove the fixation of the dye species by the macromolecules. The apparent $\mathrm{pK}_{\mathrm{a}}^{\text {app }}$ values can be obtained by conventional equating of the internal $\mathrm{pH}$ of the water within the films to those in the bulk buffer solutions where the films were dipped in.

Contrary to the aqueous solutions at high $\mathrm{pH}$ values, and in agreement with the micellar solutions of SDS, no changes in malachite green spectra along time were registered with the dye-doped films.

Somewhat unusual behavior exhibits the lipophilic indicator dye $n$-decylfluorescein. Its color transition varies from $\mathrm{pH} 3$ to 10 , which reflects the re-charging of the gelatin matrix. The increase in the ionic strength of the bulk aqueous phase from 0.05 to $0.50 \mathrm{~mol} \mathrm{~L}^{-1} \mathrm{did}$ not seriously change the $\mathrm{pK}_{\mathrm{a}}^{\text {app }}$ value at the given $\mathrm{pH}$.

The $\mathrm{pH}$-induced color changes of the films can be easily observed by the naked eye. For more precise monitoring of the acidity of solutions, for example, in sensor devices, spectrophotometric measurements can be used.

\section{Supplementary Information}

Supplementary data are available free of charge at http://jbcs.sbq.org.br as PDF file.

\section{Acknowledgments}

The authors are grateful to Dr. Vera I. Alekseeva (Research Institute of Organic Intermediates and Dyes, Moscow, Russia.) for her gift of the samples of $n$-decylfluorescein and $n$-decyleosin.

\section{References}

1. Munkholm, Ch.; Walt, D. R.; Milanovich, F. P.; Klainer, S. M.; Anal. Chem. 1986, 58, 1427.

2. Peterson, J. I.; Goldestein, S. R.; Fitzerald, R. V.; Buckhold, D. K.; Anal. Chem. 1980, 52, 864. 
3. Nakashima, K.; Duhamel, J.; Winnik, M. A.; J. Phys. Chem. 1993, 97, 10702.

4. Bacci, M.; Baldini, F.; Scheggi, A. M.; Anal. Chim. Acta 1988, 207, 343.

5. Narayanaswamy, R.; Sevilla, F.; Anal. Chim. Acta 1986, 189, 365.

6. Vachoud, L.; Zidowicz, N.; Domard, A.; Int. J. Biol. Macromol. 2001, 28, 93.

7. Birkedal-Hansen, H.; Histochemie 1973, 36, 73.

8. Savvin, S. B.; Shtykov, S. N.; Mikhailova, A. V.; Russ. Chem. Rev. 2006, 75, 341.

9. Mchedlov-Petrossyan, N. O.; Pure Appl. Chem. 2008, 80, 1459.

10. Drummond,C. J.; Grieser, F.; Healy, T. W.; J. Chem. Soc., Faraday Trans. 1989, 85, 551.

11. Mchedlov-Petrossyan, N. O; Isaenko, Yu. V.; Salamanova, N. V.; Alekseeva, V. I.; Savvina, L. P.; J. Anal. Chem. 2003, 58, 1018.

12. Gorbenko, G. P.; Mchedlov-Petrosyan, N. O.; Chernaya, T. A.; J. Chem. Soc., Faraday Trans. 1998, 94, 2117.

13. Hong-Wen, Gao; Jun Jiang; Lin-Qian, Yu; J. Anal. Chem. 2002, 57, 694.

14. Gao, D.; Tian, Y.; Liang, F.; Jin, D.; Chen, Y.; Zhang, H.; Ya, A.; J. Lumin. 2007, 127, 515.

15. Galat, A.; Spectrochim. Acta 1986, 42A, 199.

16. Duxbury, D. F.; Dyes Pigm. 1994, 25, 131.

17. Saleem, M.; Tahira, P.; Qadeer, R.; Colloids Surf., A 2007, 292, 246.

18. Funasaki, N.; J. Colloid Interface Sci. 1977, 60, 54.

19. Choi, M. M. F.; J. Photochem. Photobiol., A 1998, 114, 235.

20. Nakamaru, Y.; Sugii, Y.; J. Biochem. 1974, 75 , 1331.

21. Mikhailov, O. V.; Polovnyak, V. K.; Zavodsk. Laboratoriya 1989, 55, 34.

22. Mikhailov, O. V.; Rossiiskiy Khim. Zhurn. 2000, 3, 70.

23. Mikhailov, O. V.; Russ. J. Coord. Chem. 2000, 26, 750.

24. Sheremet'ev, S. V.; Kuznetsov, V. V.; J. Anal. Chem. 2007, 62, 319.

25. Loginova, L. P.; Konovalova, O. Yu.; Talanta 2008, 77, 915.

26. Loginova, L. P.; Nesterenko, O. Yu.; Kharkov University Bulletin 2006, $14,112$.

27. Ward, A. G.; Inst, P.; Br. J. Appl. Phys. 1954, 5, 85.

28. Moller, J. V.; Kragh-Hansen, U.; Biochemistry 1975, 11, 2317.

29. Loginova, L. P.; Samokhina, L. V.; Mchedlov-Petrossyan, N. O.; Alekseeva, V. I.; Savvina, L. P.; Colloids Surf., A 2001, 193, 207.

30. Hartland, G. V.; Grieser, F.; White, L. R.; J. Chem. Soc. Faraday Trans. 1 1987, 83, 591.

31. Drummond, C. J.; Grieser, F.; J. Photochem. Photobiol. 1987, 45, 19.

32. Mangaiyarkarasi, D.; Palanisamy, P. K.; Sirohi, R. S.; Optical Engineering 2000, 39, 2138.

33. Bezkrovnaya, O. N.; Mchedlov-Petrossyan, N. O.; Vodolazkaya, N. A.; Alekseeva, V. I.; Savvina, L. P.; Yakyubovskaya, A. G.; Russ. J. Appl. Chem. 2008, 81, 659.
34. Choi, M. F.; Shaomin Shuang; Analyst 2000, 125, 301.

35. Bezkrovnaya, O. N.; Mchedlov-Petrossyan, N. O.; Vodolazkaya, N. A.; Litvin, P. M.; Reports of the National Academy of Science of Ukraine 2008, 7, 130.

36. Mees, C. E.; James ,T. H.; Theory of the Photographic Process, $4^{\text {th }}$ ed, Macmillan: New York, 1977.

37. Kolthoff, I.; Die Massanalyse, $2^{\text {nd }}$ ed.; Springer: Berlin, 1931.

38. Vachoud, L.; Zidowicz, N.; Domard, A.; Int. J. Biol. Macromol. 2001, 28, 93.

39. Mchedlov-Petrossyan, N. O.; Kleschevnikova, V. N.; Zhurn. Obshch. Khim. 1990, 60, 900.

40. Mchedlov-Petrossyan, N. O.; Kleshchevnikova, V. N.; J. Chem. Soc., Faraday Trans. 1994, 90, 629.

41. Kuznetsov, V. V.; Sheremet'ev, S. V.; J. Anal. Chem. 2009, 64, 886.

42. Mchedlov-Petrossyan, N. O.; Vodolazkaya, N. A.; Vilkova, L. N.; Soboleva, O. Yu.; Kutuzova, L. V.; Rodik, R. V.; Miroshnichenko, S. I.; Drapaylo, A. B.; J. Mol. Liq. 2009, 145, 197.

43. Baumgartner, E.; Fernandez-Prini, R.; Turyn, D.; J. Chem. Soc., Faraday Trans. 1974, 70, 1518.

44. Goldacre, R. J.; Phillips, J. N.; J. Chem. Soc. 1949, 1724.

45. Ginzburg, O. F.; Zavlin, P. M.; Zh. Obshch. Khim. 1960, 30, 1479.

46. Ginzburg, O. F.; Zavlin, P. M.; Zh. Obshch. Khim. 1961, 31, 75.

47. Ginzburg, O. F.; Zavlin, P. M.; Zh. Obshch. Khim. 1962, 32, 3359.

48. Frolova, A. M.; Boichenko, A. P.; Konovalova, O. Yu.; Loginova, L. P.; Kharkov University Bulletin 2009, 17, 157.

49. Bishop, E.; Indicators, Pergamon Press: Oxford, 1972.

50. Reshetnyak, E. A.; Nikitina, N. A.; Loginova, L. P.; MchedlovPetrossyan, N. O.; Svetlova, N. V.; Kharkov University Bulletin 2005, 13, 67.

51. Gohain, B.; Boruah, B.; Saikia, P. M.; Dutta, R.; J. Phys. Org. Chem 2010, 23, 211.

52. Basahl, S. N.; El-Arab, M. A. F. E.; Gasem, A. A.; Emara, M. M.; Indian J. Chem. 1986, 25A, 544.

53. Kholin, Yu. V.; http://www-chemo.univer.kharkov.ua/kholin/ clinp.html accessed in January 2011.

54. Mchedlov-Petrossyan, N. O.; Rubtsov, M. I.; Lukatskaya, L. L.; Ukr. Khim. Zh. 1990, 56, 69.

55. Zaslavsky, B. Yu.; Miheeva, L. M.; Gulaeva, N. D.; Borovskaya, A. A.; Rubtsov, M. I.; Lukatskaya, L. L.; Mchedlov-Petrossyan, N. O.; J. Chem. Soc., Faraday Trans. 1991, 87, 931.

56. Mudakavi, J. R.; Analyst 1984, 109, 1577.

57. Weidgans, B. M.; Krause, C.; Klimant, I.; Wolfbeis, O. S.; Analyst 2004, 129, 645.

Submitted: August 27, 2010

Published online: February 1, 2011 


\section{Protolytic Properties of Dyes Embedded in Gelatin Films}

\section{Nataliya A. Nikitina, * Elena A. Reshetnyak, Nataliya V. Svetlova and Nikolay O. Mchedlov-Petrossyan}

Kharkov V. N. Karazin National University, Kharkov, 61077, Ukraine

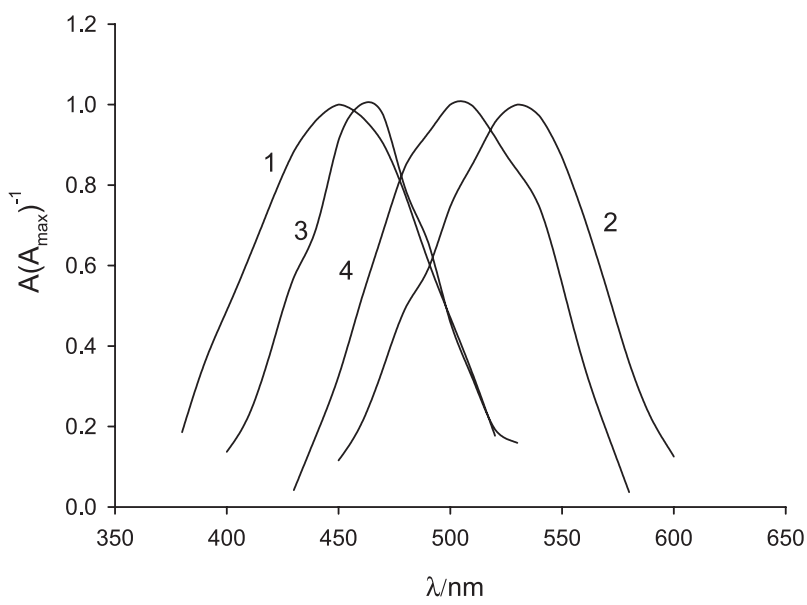

Figure S1. Normalized absorption spectra of the $\mathrm{R}$ form $(1,3)$ and $\mathrm{HR}^{+}$form $(2,4)$ of neutral red in aqueous solutions at $\mathrm{pH} 10.0$ and 4.0, respectively $(1,2)$ and in the gelatin film at $\mathrm{pH} 10.5$ and 6.0 , respectively $(3,4)$

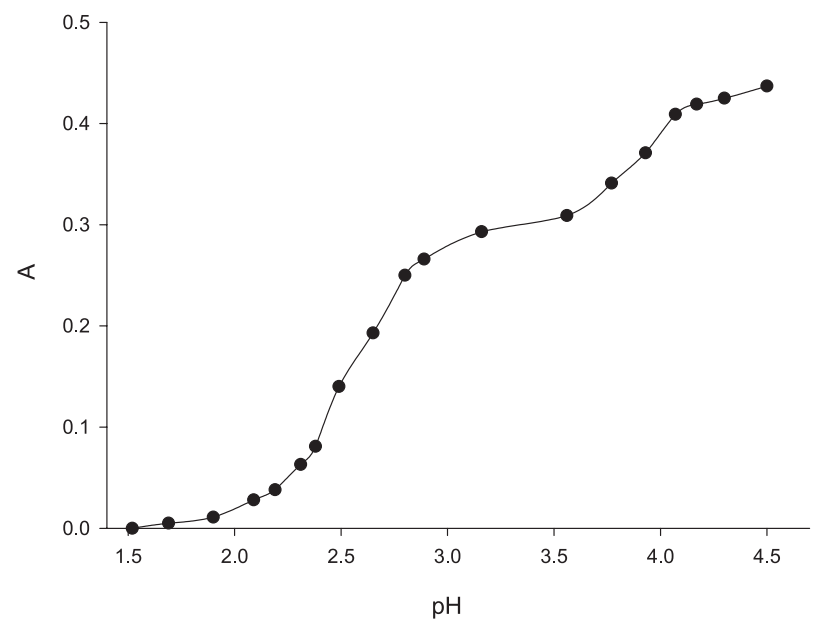

Figure S2. Dependence of absorbance of eosin $(\lambda=534 \mathrm{~nm})$, immobilized in the gelatin film, on $\mathrm{pH}$ of the aqueous; $\mathrm{I}=0.05 \mathrm{~mol} \mathrm{~L}^{-1}, \mathrm{NaCl}$. 